\title{
Genomics Testing in Head and Neck Cancers: Is there a Benefit?
}

\author{
Ravi C Nayar ${ }^{1}$, Richitha V Pandit ${ }^{2}$, Vishal US Rao ${ }^{3}$, Mithua V Ghosh ${ }^{4}$, Sataksi Chatterjee ${ }^{5}$
}

\begin{abstract}
Introduction: Elucidation of the genomic basis of head and neck cancers (HNCs) may help in reducing cancer-related mortality and morbidity. This is because prognostication by predicting disease course and treatment response will help to individualize treatment protocols.

Materials and methods: This prospective pilot study used a 48-gene mutation panel on tumor tissue samples obtained from 18 patients suffering from HNCs. The clinical significance of these mutations was analyzed in terms of treatment resistance, presence of distant metastasis, family history, and disease recurrence.

Results: Two patients carried germline mutations, nine carried somatic mutations and seven samples had no mutation detected on the 48-gene panel. The genomic studies detected germline mutations in BRCA and AIP, and somatic mutations in TP53, phosphatase and tensin homolog (PTEN), RB1, STK11, GNA11, and HRAS.

Conclusion: The study appears to validate early genomic testing of HNC cases to modify treatment protocols and offers more specific and personalized treatment options to patients.

Clinical significance: The study demonstrates the potential benefit of integrating genomic data with clinical details to map out a tailored treatment plan to benefit individual patients.

Keywords: Actionable mutations, Cancer genomics, Head and neck cancers, Head and neck squamous cell carcinoma (HNSCC).

International Journal of Head and Neck Surgery (2021): 10.5005/jp-journals-10001-1420
\end{abstract}

\section{INTRODUCTION}

Head and neck cancers (HNCS) contribute to a significant portion of cancer-related mortality and morbidity worldwide. ${ }^{1}$ Despite advances in multimodality treatments, the overall survival has not improved significantly over time. ${ }^{2}$ Genomic profiling of HNCs elucidates the biological basis of the individual tumor pathogenesis, identifies potential carcinogens, aids in the identification of diagnostic and prognostic markers and choice of targeted therapy ${ }^{3}$ hence, may impact on the clinical outcome.

We conducted a prospective pilot study on samples obtained from $18 \mathrm{HNC}$ patients, to assess the nature of genetic alteration to clarify potential benefit.

\section{Materials and Methods}

The patients of HNC, presenting to the Head and Neck clinic of Health Care Global Hospital, a tertiary referral oncology hospital, in Bengaluru, South India, from May 24, 2011, to November 11, 2016, were chosen for this study, which was funded internally as a proof-of-concept study.

The approval of the scientific research committee and Institutional Ethics Review Board (IERB) was obtained (No. 2017/02/06). Informed consent about the limited applicability to current treatment protocols, though with a possibility of future benefits but was obtained from patients. The clinical data of the patients including details of family history of cancers were obtained from the referring oncologist and, whenever possible through pretest genetic counseling by a genetic counselor.

The tissue samples (paraffin-embedded tissue/fresh frozen tissue) were obtained from 18 patients diagnosed with tumors of the head and neck. To assess tumor tissue quality, a small section of each biopsy $\left(3-5 \mathrm{~mm}^{3}\right)$ was cut, fixed in formalin, and stained with

\footnotetext{
1,2Department of Academics, Centre for Academic Research, Health Care Global Hospitals, Bengaluru, Karnataka, India

${ }^{3}$ Department of Head and Neck Oncology, Head Neck Surgery; Health Care Global Hospitals, Bengaluru, Karnataka, India

${ }^{4}$ Department of Research and Development, Strand Life Sciences (A Unit of Health Care Global Enterprises Limited), Bengaluru, Karnataka, India

${ }^{5}$ Department of Head and Neck Surgical Oncology, Health Care Global Hospitals, Bengaluru, Karnataka, India

Corresponding Author: Ravi C Nayar, Department of Academics, Centre for Academic Research, Health Care Global Hospitals, Bengaluru, Karnataka, India, Phone: +91 8042862250, e-mail: hcgdeanacademics@gmail.com

How to cite this article: Nayar RC, Pandit RV, Rao VUS, et al. Genomics Testing in Head and Neck Cancers: Is there a Benefit? Int J Head Neck Surg 2021;12(2):58-64.

Source of support: Nil

Conflict of interest: None
}

hematoxylin and eosin (H\&E) for scoring by an oncopathologist (HCG). These slides were scored for the percentage volume of the tumor. The methodology for sequencing has been outlined in Appendix 1.

The genes included in the panel are listed in Table 1.

A brief explanation of the terms used.

\section{Somatic and Germline Mutations \\ Germline Mutations}

These are the mutations that occur within the germ cells. They are seen to be present in all the cells of an organism and are passed on to the next generation. Testing for germline mutations can be 


\begin{tabular}{cl}
\multicolumn{2}{l}{ Table 1: Distribution of mutations in various chromosomes } \\
\hline Chromosome number & Genes affected \\
\hline 1 & MPL, NRAS \\
2 & ALK, ERBB4, IDH1 \\
3 & PIK3CA, MLH1, PDGFRA, VHL \\
4 & FGFR3, KDR, KIT \\
5 & CDH1, APC, CSF1R, NPM1 \\
7 & EGFR, BRAF, MET, SMO \\
8 & FGFR1 \\
9 & NOTCH1, CDKN2A/B, ABL1, GNAQ, JAK2 \\
10 & FGFR2, PTEN, RET \\
11 & HRAS, ATM \\
12 & HNF1A, KRAS, PTPN11 \\
13 & FLT3, RB1 \\
14 & AKT1 \\
18 & SMAD4 \\
19 & GNA11, JAK3, STK11 \\
20 & SRC, GNAS \\
22 & SMARCB1
\end{tabular}

done on a blood sample or a buccal mucosal swab. ${ }^{4}$ Some germline mutations that are associated with HNCs are FANC, ${ }_{1}^{5}$ p16/p14ARF, NSD1, ${ }^{7}$ CDKN2A, and ATR. ${ }^{8}$

\section{Somatic Mutations}

These are acquired by individual cells. A population of cells derived by the asexual reproduction of this cell, forming a clone, generally comprise the cells of the tumor. ${ }^{9}$

\section{Actionable and Non-actionable Mutations}

A subset of driver mutations having diagnostic, prognostic, or therapeutic significance is known as actionable mutations, while those that are not as clinically significant are known as nonactionable mutations. These actionable mutations include those for which FDA approved drugs are available, even if recommended for use in tumors of other sites. ${ }^{10}$

\section{Results}

The age distribution of the patients ranged from 9 to 74 years, with a median age of 45.94 years. There were 14 males and 4 females in the group. Family history was obtained from 17 patients of whom 4 had a family history of other cancers ( 2 patients had siblings with a history of other cancers and 2 had parents with a history of other cancers). Their origins were diverse (15 patients were Indians, 2 patients were of Middle Eastern origin, and 1 patient belonged to the island of Maldives).

There were nine patients with a history of exposure to tobacco, two with alcohol consumption history while the others did not report any risk factors.

The genomic study revealed germline mutations in $B R C A$ (in a patient with carcinoma nasopharynx) and AIP (in a patient with adenoid cystic carcinoma of the right submandibular gland), somatic mutations in TP53 in three patients with squamous cell carcinoma (one case of SCC of the tongue, one with SCC of the gingivobuccal sulcus, and the third involving the oropharynx and base of the tongue) and HRAS in three patients (in a case of metastatic papillary thyroid cancer, a case of malignancy of unknown origin, and a case of SCC of the tongue), while the other mutations detected were STK11 (in a patient with mucoepidermoid carcinoma of the hard palate), GNA11 (in metastatic alveolar sarcoma of the tongue), phosphatase and tensin homolog (PTEN), and RB1 (in a case of SCC involving the gingivobuccal sulcus and the base of the tongue).

The remaining samples four cases of SCC (one involving the pyriform sinus, one involving both the oropharynx and pyriform sinus, one of the tongue, and the fourth, SCC of the buccal mucosa) and two cases of mucoepidermoid carcinoma (of the right parotid and one patient with carcinoma of the base of tongue) showed no mutation as seen by the 48-gene panel, while one sample belonging to a patient of papillary carcinoma thyroid failed quality control testing.

These mutations are described in Table 2 and their potential significance explained in the discussion.

\section{Discussion and Clinical Significance}

TP53 is the most commonly mutated gene in HNC patients in studies conducted by Agrawal et al. and Stransky et al. on 32 and 74 samples, respectively. HPV-positive cancers were $100 \%$ positive for E6 and E7 oncogenes. The other mutations that were picked up in significant numbers were SYNE1, NOTCH1, and HRAS. ${ }^{11,12}$

Pickering et al. conducted two studies on oral squamous cell cancer and on carcinoma tongue specimens in the years 2013 and 2014, respectively. Among the samples in both the studies, CDKN2A and TP53 were the common mutations picked up. ${ }^{13,14}$ In a study conducted by Lin et al. on 128 samples of nasopharyngeal carcinoma, a mutation in TP53 was seen in 17\%, CDKN2A in 13\%, and ARID1A in $11 \%$ samples. Less than $10 \%$ of tissue samples showed the presence of mutations in SYNE1, ATG13, MLL2, PIK3CA, CCND1, NOTCH3, and FGFR2. ${ }^{15}$

In 2015, Seiwert et al. and The Cancer Genome Atlas (TCGA) conducted genomic studies on both HPV-positive and -negative tumor tissue samples separately and found that in the HPV-negative group, the most commonly mutated gene was TP53 followed by CDKN2A, while in the HPV-positive group, E6/E7 were positive in $100 \%$ samples and the second most commonly mutated gene was PIK3CA. ${ }^{7,16}$

In 2018, a targeted sequencing conducted by Perdomo et al. on 180-paired diagnosed samples of head and neck squamous cell carcinoma (HNSCC) revealed the most frequently mutated genes to be TP53, PIK3CA, NOTCH1, TP63 and CDKN2A. ${ }^{17}$

The mutations detected commonly in the above studies conducted from 2011 to 2015 were TP53, EGFR, HRAS, NOTCH1/2/3, CDKN3A, CCND1, PIK3CA, and ATM. E6 and E7 oncogenes were seen to be expressed in HPV-positive cancers (Table 3).

In our study, germline mutations were detected in two patients-AIP and BRCA, while somatic mutations were detected in nine patients. These were TP53, PTEN, RB, STK11, GNA11, and HRAS. TP53 and HRAS were seen in $16.67 \%$ of patients each while the other mutations were detected in $5.5 \%$ of patients each.

\section{Significance of Gene Mutations Detected in OUR Study}

\section{Germline Mutations}

AIP

This is a tumor suppressor gene (TSG), a mutation in which was detected in $5.5 \%$ of patients in this study. 
Table 2: Results—-mutations detected and their potential significance

\begin{tabular}{|c|c|c|c|c|c|c|c|c|}
\hline Age & Sex & Diagnosis & Histological type & TNM stage & Risk factors & Distant metastasis & Recurrence & Genes detected \\
\hline 27 & $M$ & $\begin{array}{l}\text { Adenoid cystic } \\
\text { carcinoma-right } \\
\text { submandibular } \\
\text { gland }\end{array}$ & $\begin{array}{l}\text { Adenoid } \\
\text { cystic carci- } \\
\text { noma-grade I, } \\
\text { submandibular } \\
\text { gland }\end{array}$ & T1 N0 M0 & None & Absent & No & AIP \\
\hline 22 & $\mathrm{~F}$ & Ca nasopharynx & & N2 & None & Absent & No & $B R C A$ \\
\hline 72 & M & $\begin{array}{l}\text { Papillary carcinoma } \\
\text { thyroid }\end{array}$ & $\begin{array}{l}\text { Follicular } \\
\text { variant }\end{array}$ & & None & Cervical vertebrae & Yes & $\begin{array}{l}\text { HRAS-poor } \\
\text { response to } \\
\text { cetuximab }\end{array}$ \\
\hline 42 & M & $\begin{array}{l}\text { Squamous cell } \\
\text { carcinoma right } \\
\text { gingivobuccal } \\
\text { sulcus }\end{array}$ & $\begin{array}{l}\text { Squamous cell } \\
\text { carcinoma }\end{array}$ & T2 NO MO & $\begin{array}{l}\text { Alcohol, } \\
\text { tobacco }\end{array}$ & Absent & No & TP53 \\
\hline 41 & M & $\begin{array}{l}\text { Squamous cell car- } \\
\text { cinoma tongue }\end{array}$ & $\begin{array}{l}\text { Squamous cell } \\
\text { carcinoma of } \\
\text { the tongue }\end{array}$ & pT2 N2b M0 & Tobacco & Absent & No & $\begin{array}{l}\text { TP53-poor } \\
\text { response to } \\
\text { cisplatin }\end{array}$ \\
\hline 9 & M & $\begin{array}{l}\text { Metastatic alveolar } \\
\text { sarcoma of the } \\
\text { tongue }\end{array}$ & Not done & M1 & None & Lungs & No & GNA11 \\
\hline 66 & M & $\begin{array}{l}\text { Squamous cell car- } \\
\text { cinoma neck with } \\
\text { metastasis }\end{array}$ & $\begin{array}{l}\text { Metastatic } \\
\text { poorly differen- } \\
\text { tiated carci- } \\
\text { noma-left neck } \\
\text { node biopsy }\end{array}$ & N1 & None & $\begin{array}{l}\text { Right kidney and ad- } \\
\text { renal, diaphragmatic } \\
\text { crura, left lobe of liver, } \\
\text { L2 vertebra, Rt renal } \\
\text { hilar, retroperitoneal, } \\
\text { periportal, portacaval, } \\
\text { pancreaticoduodenal, } \\
\text { retrocrural, and lower } \\
\text { cervical lymph nodes }\end{array}$ & No & HRAS \\
\hline 63 & M & $\begin{array}{l}\text { Carcinoma oro- } \\
\text { pharynx }+ \text { base of } \\
\text { the tongue }\end{array}$ & $\begin{array}{l}\text { Metastatic } \\
\text { squamous cell } \\
\text { carcinoma dif- } \\
\text { ferentiation }\end{array}$ & $\mathrm{T} 1 \mathrm{~N} 2 \mathrm{~b} \mathrm{M} 0$ & $\begin{array}{l}\text { Alcohol, } \\
\text { tobacco }\end{array}$ & Absent & Yes & $\begin{array}{l}\text { TP53-poor } \\
\text { response to the } \\
\text { combination } \\
\text { of cisplatin and } \\
\text { 5-fluorouracil }\end{array}$ \\
\hline 55 & M & $\begin{array}{l}\text { Squamous cell car- } \\
\text { cinoma tongue }\end{array}$ & $\begin{array}{l}\text { Moderately } \\
\text { differentiated } \\
\text { squamous cell } \\
\text { carcinoma }\end{array}$ & pT2 N1 M0 & Tobacco & Absent & Yes & $\begin{array}{l}\text { HRAS-poor } \\
\text { response to } \\
\text { cetuximab }\end{array}$ \\
\hline 53 & M & $\begin{array}{l}\text { Surgically operated } \\
\text { case of left hard } \\
\text { palate mucoepi- } \\
\text { dermoid carcinoma } \\
\text { (recurrent high- } \\
\text { grade tumor) }\end{array}$ & $\begin{array}{l}\text { S/o recurrence } \\
\text { of mucoepider- } \\
\text { moid carcinoma }\end{array}$ & T4a No M0 & Tobacco & Absent & Yes & $\begin{array}{l}\text { STK11-recur- } \\
\text { rence }\end{array}$ \\
\hline 27 & M & $\begin{array}{l}\text { Squamous cell } \\
\text { carcinoma-left } \\
\text { mandible }\end{array}$ & $\begin{array}{l}\text { Moderately } \\
\text { differentiated } \\
\text { SCC of the left } \\
\text { lower alveolus, } \\
\text { gingivobuccal } \\
\text { sulcus invading } \\
\text { to a depth of } \\
6 \mathrm{~mm}\end{array}$ & T4 NO MO & Tobacco & Absent & No & PTEN, RB1 \\
\hline 74 & M & $\begin{array}{l}\text { Squamous cell car- } \\
\text { cinoma of the left } \\
\text { pyriform fossa }\end{array}$ & $\begin{array}{l}\text { Moderately } \\
\text { differentiated } \\
\text { keratinizing } \\
\text { squamous cell } \\
\text { carcinoma }\end{array}$ & T1N0M0 & Tobacco & Lungs, bones-S1, S2 & No & No mutation \\
\hline
\end{tabular}




\begin{tabular}{|c|c|c|c|c|c|c|c|c|}
\hline Age & Sex & Diagnosis & Histological type & TNM stage & Risk factors & Distant metastasis & Recurrence & Genes detected \\
\hline 17 & $\mathrm{~F}$ & $\begin{array}{l}\text { Mucoepidermoid } \\
\text { ca base of tongue }\end{array}$ & $\begin{array}{l}\text { Mucoepider- } \\
\text { moid carci- } \\
\text { noma-with } \\
\text { mucinous } \\
\text { component } \\
\text { mostly }\end{array}$ & T1 No Mo & None & Absent & No & No mutation \\
\hline 73 & M & $\begin{array}{l}\text { Ca left oropharynx } \\
+ \text { pyriform fossa }\end{array}$ & $\begin{array}{l}\text { Squamous cell } \\
\text { carcinoma }\end{array}$ & T3 NO MO & None & Absent & No & No mutation \\
\hline 50 & M & $\begin{array}{l}\text { Mucoepidermoid } \\
\text { tumor-right pa- } \\
\text { rotid gland }\end{array}$ & $\begin{array}{l}\text { Mucoepider- } \\
\text { moid tumor }\end{array}$ & & Tobacco & Absent & No & No mutation \\
\hline 40 & $\mathrm{~F}$ & $\begin{array}{l}\text { Squamous cell car- } \\
\text { cinoma-left buccal } \\
\text { mucosa }\end{array}$ & $\begin{array}{l}\text { Squamous } \\
\text { cell carcinoma } \\
\text { grade II }\end{array}$ & & None & Absent & No & No mutation \\
\hline 49 & M & $\begin{array}{l}\text { Recurrent carci- } \\
\text { noma tongue }\end{array}$ & $\begin{array}{l}\text { Squamous cell } \\
\text { carcinoma }\end{array}$ & T3 NO MO & Tobacco & Absent & Yes & No mutation \\
\hline 47 & $\mathrm{~F}$ & $\begin{array}{l}\text { Papillary carcinoma } \\
\text { thyroid }\end{array}$ & $\begin{array}{l}\text { Papillary carci- } \\
\text { noma thyroid } \\
\text { with metastasis } \\
\text { to lymph nodes } \\
\text { with extracap- } \\
\text { sular extension }\end{array}$ & T4 N1 M0 & None & Absent & No & QC failed \\
\hline
\end{tabular}

The AIP gene product is involved in aryl hydrocarbon receptormediated signaling, the mutation of which is familial. ${ }^{18}$

AIP mutation in tumors is associated with an earlier onset, aggressive behavior, and poor response to treatment. ${ }^{19}$

In our study, a germline mutation in AIP was detected in a patient with adenoid cystic carcinoma-right submandibular gland who is only 27 years old. It was, however, not a recurrent tumor and responded well to therapy. He did not have any metachronous tumors or a family history of cancer. The patient is now being followed up closely.

\section{$B R C A$}

This is a TSG, a mutation in which was seen in $5.5 \%$ of patients in this study.

This gene product is involved in the repair of chromosomal damage with an important role in the error-free repair of DNA double-stranded breaks. ${ }^{20}$ Germline mutations resulting in upregulation of TSG function, when left unchecked by repair genes, cause cancer.

The tumors harboring this mutation show resistance to cisplatin and poly (ADP-ribose) polymerase (PARP) inhibitors. ${ }^{21}$

A germline mutation of $B R C A$ was detected in a case of carcinoma nasopharynx in a patient with a synchronous BIRADS 2 lesion in the left breast and a family history of two sisters having had breast cancer. No changes were recommended to the standard treatment protocol.

\section{Somatic Mutations HRAS}

This is an oncogene, a mutation in which was seen in $16.67 \%$ of patients in this study. A mutation in this gene was seen in $11 \%$ of patients as seen in a genomic study on HNCs conducted by Agrawal et al. ${ }^{11}$ The activated allele of HRAS triggers the expression of transcription factors associated with proliferation. ${ }^{22}$ The expression of HRAS is associated with treatment resistance. This mutation predisposes to cetuximab resistance in tumors which express EGFR mutations. ${ }^{23}$ A mutation in HRAS is more common in Indian as compared to western patients, with a strong association with betel quid and smoking. ${ }^{24}$

In our study, HRAS was detected in a case of SCC with recurrence and resistance to cetuximab and a case of MUO.

\section{PTEN}

This is a TSG, a mutation in which was seen in $5.5 \%$ of patients in this study.

Phosphatase and tensin homolog is a protein encoded by the PTEN gene. A reduced number of copies in a pseudogene of PTEN, PPTEN1 has been detected in cases of HNSCCs. ${ }^{25}$ The reduced expression of PTEN is associated with tobacco exposure, higher relapse rates, poor response, and survival rates. ${ }^{26,27}$

In our study, PTEN was detected in a 27-year-old male patient suffering from moderately differentiated SCC of GBS invading the lower alveolus, with a history of tobacco use, family history of cancer, who responded well to chemotherapy. A closer follow-up to detect recurrences and counseling for tobacco avoidance was advised.

\section{STK11}

This is a TSG, a mutation in which was seen in $5.5 \%$ of patients in this study. The STK11 gene is also known as the liver kinase B1 (LKB1) gene. It regulates cell polarity and also functions as a TSG. ${ }^{28}$

It was detected in a recurrent case of mucoepidermoid cancer in this study.

\section{$R B$}

This is a TSG. A mutation in RB was seen in $5.5 \%$ of patients in this study. The Rb gene negatively regulates the cell cycle by inhibiting cyclin-dependent kinases. It blocks the entry of cells from the G1 phase to the $S$ phase. It is also involved in epigenetic changes as it 
Table 3: Gene mutations in head and neck cancers detected in various studies

\begin{tabular}{|c|c|c|}
\hline \multirow[t]{2}{*}{ Agrawal et al. ${ }^{11}$} & 2011 & $\begin{array}{l}\text { TP53, NOTCH1, RELN, SYNE1, } \\
\text { EPHA7, FLG, HRAS, PIK3AP1, } \\
\text { RIMBP2, SI }\end{array}$ \\
\hline & & $\begin{array}{l}\text { HPV+: E6/E7, EPHB3, UNC5D, } \\
\text { NLRP12, PIK3CA, TM7SF3, } \\
\text { ENPP1, NRXN3, MICAL2 }\end{array}$ \\
\hline \multirow[t]{2}{*}{ Stransky et al. ${ }^{12}$} & 2011 & $\begin{array}{l}\text { TP53, CDKN2A, SYNE1, CCND1, } \\
\text { MUC16, USH2A, FAT1, LRP1B, } \\
\text { ZFHX4, NOTCH1 }\end{array}$ \\
\hline & & $\begin{array}{l}\text { HPV+: E6/E7, PIK3CA, RUFY1, } \\
\text { EZH2, CDH10, THSD7A, FAT4, } \\
\text { KMT2D, ZNF676, MUC16 }\end{array}$ \\
\hline Cadoni et al. ${ }^{31}$ & 2012 & $\begin{array}{l}\text { CYP2E1, CYP1A1, GSTM1, } \\
\text { GSTT1, GSTP1, NAT2, EPHX1, } \\
\text { ALDH2, ADH, XRCC1, XPD, } \\
\text { Cyclin D1, P53, P73 }\end{array}$ \\
\hline Pickering et al. ${ }^{13,14}$ & 2013-14 & $\begin{array}{l}\text { TP53, CDKN2A, FAT1, TP63, } \\
\text { CSMD1, PIK3CA, FADD/CCND1, } \\
\text { MAML1, EGFR, NOTCH1, } \\
\text { TNK2, AKT1, HLA-A, } \\
\text { CASP8, SRC }\end{array}$ \\
\hline Lin et al. ${ }^{15}$ & 2014 & $\begin{array}{l}\text { TP53, CDKN2A/B, ARID1A, } \\
\text { SYNE1, ATG13, MLL2, PIK3CA, } \\
\text { CCND1, NOTCH3, FGFR2 }\end{array}$ \\
\hline \multirow[t]{2}{*}{ Seiwert et al. ${ }^{16}$} & 2015 & $\begin{array}{l}\text { TP53, CDKN2A, MDM2, MLL2, } \\
\text { NOTCH1, CCND1, PIK3CA, } \\
\text { PIK3CB, UBR5, EGFR, FGFR2 }\end{array}$ \\
\hline & & $\begin{array}{l}\text { HPV+: E6/E7, PIK3CA, TP63, } \\
\text { PIK3CB, FGFR3, NF1/2, SOX2, } \\
\text { ATM, FLG, MLL3 }\end{array}$ \\
\hline \multirow[t]{2}{*}{$\begin{array}{l}\text { The Cancer Genome } \\
\text { Atlas }^{7}\end{array}$} & 2015 & $\begin{array}{l}\text { TP53, CDKN2A, let-7c, } \\
\text { PIK3CA, FADD, FAT1, CCND1, } \\
\text { NOTCH1/2/3, TP63, EGFR, } \\
\text { SMAD4, FGFR1 }\end{array}$ \\
\hline & & $\begin{array}{l}\text { HPV+: E6/E7, PIK3CA, TP63, } \\
\text { TRAF3, E2F1, let-7C, } \\
\text { NOTCH1/3, FGFR3, HLA-A/B, } \\
\text { EGFR }\end{array}$ \\
\hline
\end{tabular}

HPV+: HPV-positive cancers

induces the enzyme histone deacetylase. ${ }^{29}$ Mutations in RB have therapeutic implications. Pharmacologically targeting the RB-E2F pathway and the use of EFGR antagonists in the absence of E2F regulation are being currently studied. ${ }^{30}$

\section{P53}

This is a TSG, a mutation of which was seen in $16.67 \%$ of patients in this study. A mutation in p53 was seen in $17 \%$ of cases in a study conducted by Lin et al., whereas various other studies show the incidence of this mutation in HNCs to be 66 to $94 \%$. $^{7,11-16,31}$ The inheritance of only one functional copy of the TP53 gene results in the development of tumors in early adulthood, a disorder known as Li-Fraumeni syndrome. ${ }^{32}$ The presence of the germline mutation predisposes individuals to second cancer, around 30 years after the first. As it undergoes a germline mutation, it has also been identified in the normal epithelial cells in patients suffering from SCC. ${ }^{24,33}$ It is the most commonly mutated gene in human cancers. ${ }^{34}$
This gene can also be modified by chemicals, radiation, viruses, or other mutagens.

Such modifications increase the likelihood of uncontrolled cell division. It is known to be associated with tobacco exposure, increased relapse rates, short survival, poor differentiation, and resistance to 5 -FU and cisplatin. ${ }^{24,35,36}$ A mutation in p53 was detected in a recurrent case of SCC showing poor response to a combination of cisplatin and 5-FU. There is intratumor heterogeneity with respect to $\mathrm{p} 53$ mutations in tobacco-associated cancers. Therefore, targeted therapy in these cases might not be very successful. ${ }^{37}$

\section{GNA11}

A mutation in this gene was seen in $5.5 \%$ of patients in this study.

The GNA11 gene, along with its paralogues GNAQ and GNAS, code for proteins of the transmembrane G-protein-coupled receptors and their products. A mutated GNA11 gene is seen to be associated with metastatic disease and poor prognosis. These are more common than GNAS and GNAQ mutations. ${ }^{38} \mathrm{~A}$ mutation in GNA11 was seen in a patient with alveolar sarcoma of the tongue which had metastasized to the lungs. The patient received chemoradiation. He was also treated with transarterial chemoembolization (TACE). He died of cardiac arrest during an embolization procedure for the tumor site bleed.

\section{Conclusion}

The current study identified somatic mutations in 9 out of 18 cases using a 48-gene panel of targetable mutations and 2 germline mutations. Though preliminary, the study appears to validate early genomic testing of HNC cases to modify treatment protocols (personalized medicine).

The discrepancy between mutations identified in the literature and our study, argues for the development of a larger customized panel of genes to be validated for personalized medicine in HNC cases in our setting. The rationale for a limited panel as against whole-genome sequencing would be the economic viability of the latter option.

\section{References}

1. Gupta B, Johnson NW, Kumar N. Global epidemiology of head and neck cancers: a continuing challenge. Oncology 2016;91(1):13-23. DOI: 10.1159/000446117.

2. Hedberg ML, Goh G, Chiosea SI, et al. Genetic landscape of metastatic and recurrent head and neck squamous cell carcinoma. J Clin Invest 2016;126(1):169-180. DOI: 10.1172/JCI82066.

3. Borad MJ, Egan JB, Condjella RM, et al. Clinical implementation of Integrated genomic profiling in patients with advanced cancers. Sci Rep 2016;6(1):25. DOI: 10.1038/s41598-016-0021-4.

4. Idowu MO, Dumur Cl, Garrett CT. Molecular Oncology Testing for Solid Tumors: A Pragmatic Approach. 1st ed., Switzerland: Springer; 2015.

5. Greaves M, Maley CC. Clonal evolution in cancer. Nature 2012;481(7381):306-313. DOI: 10.1038/nature10762.

6. Lang J, Borchers J, Danahey D, et al. Mutational status of overexpressed p16 in head and neck cancer: evidence for germline mutation of p16/p14ARF. Int J Oncol 2002;21(2):401-408. DOI: 10.3892/ijo.21.2.401. https://www.ncbi.nlm.nih.gov/pubmed/ 12118338. 
7. Cancer genome atlas network. Comprehensive genomic characterization of head and neck squamous cell carcinomas. Nature 2015;517(7536):576-582. DOI: 10.1038/nature14129.

8. Riaz N, Morris LG, Lee W, et al. Unraveling the molecular genetics of head and neck cancer through genome-wide approaches. Genes and Diseases 2014;1(1):75-86. DOI: 10.1016/j.gendis.2014. 07.002.

9. Griffiths AJF, Miller JH, Suzuki DT, et al. An Introduction to Genetic Analysis. 7th ed., New York: W. H. Freeman; 2000.

10. Dancey JE, Bedard PL, Onetto N, et al. The genetic basis for cancer treatment decisions. Cell 2012;148(3):409-420. DOI: 10.1016/j. cell.2012.01.014.

11. Agrawal N, Frederick MJ, Pickering CR, et al. Exome sequencing of head and neck squamous cell carcinoma reveals inactivating mutations in NOTCH1. Science 2011;333(6046):1154-1157. DOI: 10.1126/science.1206923.

12. Stransky N, Egloff AM, Tward AD, et al. The mutational landscape of head and neck squamous cell carcinoma. Science 2011;333(6046):11571160. DOI: $10.1126 /$ science. 1208130.

13. Pickering CR, Zhang J, Yoo SY, et al. Integrative genomic characterization of oral squamous cell carcinoma identifies frequent somatic drivers. Cancer Discov 2013;3(7):770-781. DOI: 10.1158/21598290.CD-12-0537.

14. Pickering $C R$, Zhang J, Neskey DM, et al. Squamous cell carcinoma of the oral tongue in young non-smokers is genomically similar to tumors in older smokers. Clin Cancer Res 2014;20(14):3842-3848. DOI: 10.1158/1078-0432.CCR-14-0565.

15. Lin DC, Meng $X$, Hazawa $M$, et al. The genomic landscape of nasopharyngeal carcinoma. Nat Genet 2014;46(8):866-871. DOI: 10.1038/ng.3006.

16. Seiwert TY, Zuo Z, Keck MK, et al. Integrative and comparative genomic analysis of HPV-positive and HPV negative head and neck squamous cell carcinomas. Clin Cancer Res 2015;21(3):632-641. DOI: 10.1158/1078-0432.CCR-13-3310.

17. Perdomo S, Anantharaman D, Foll M, et al. Genomic analysis of head and neck cancer cases from two high incidence regions. PLoS ONE 2018;13(1):e0191701. DOI: https://doi.org/10.1371/journal. pone.0191701.

18. Lloyd C, Grossman A. The AIP (aryl hydrocarbon receptor-interacting protein) gene and its relation to the pathogenesis of pituitary adenomas. Endocrine 2014;46(3):387-396. [Online]. Available at: 10.1007/s12020-013-0125-6.

19. Chahal HS, Chapple JP, Frohman LA, et al. Clinical, genetic and molecular characterization of patients with familial isolated pituitary adenomas (FIPA). Trends Endocrinol Metab 2010;21(7):419-427. [Online]. Available at: 10.1016/j.tem.2010.02.007.

20. Welcsh PL, King MC. BRCA1 and BRCA2 and the genetics of breast and ovarian cancer. Hum Mol Genet 2001;10(7):705-713. DOI: 10.1093/ hmg/10.7.705[Online]. Available at: https://www.ncbi.nlm.nih.gov/ pubmed/11257103.

21. Sakai W, Swisher EM, Karlan BY, et al. Secondary mutations as a mechanism of cisplatin resistance in BRCA2-mutated cancers. Nature 2008;451(7182):1116-1120. [Online]. Available at: 10.1038/ nature06633.

22. De Vita Jr. VT, Lawrence TS, et al. DeVita, Hellman and Rosenberg's Cancer Principles and Practice of Oncology, vol. p2-42 10th ed., USA: Wolters Kluwer Health; 2015. pp. 416-422.
23. Rampias T, Giagini A, Siolos S, et al. RAS/PI3K crosstalk and cetuximab resistance in head and neck squamous cell carcinoma. Clin Cancer Res 2014;20(11):2933-2946. DOI: 10.1158/1078-0432.CCR-13-2721[Online]. Available at: https://www.ncbi.nlm.nih.gov/pubmed/24696319.

24. Nagai MA. Genetic alterations in head and neck squamous cell carcinomas. Head and Neck Cancer Brazil J Med Biolog Res 1999;32(7):897-904.DOI: 10.1590/S0100-879X1999000700015[Online]. Available at: http://scielo.br/pdf/bjmbr/v32n7/3409c.pdf.

25. Liu J, Xing $Y, X u L$, et al. Decreased expression of pseudogene PTENP1 promotes malignant behaviours and is associated with the poor survival of patients with HNSCC. Nature: Scient Rep 2017;7(41179):[Online]. Available at: 10.1038/srep41179.

26. Snietura M, Jaworska M, Mlynarczyk-Liszka J, et al. PTEN as a prognostic and predictive marker in postoperative radiotherapy for squamous cell cancer of the head and neck. PLoS ONE 2012;7(3):e33396. DOI: 10.1371/journal.pone.0033396.

27. Du L, Shen J, Weems A, et al. Role of phosphatidylinositol-3-kinase pathway in head and neck squamous cell carcinoma. J Oncol 2012;2012:450179. [Online]. Available at: 10.1155/2012/450179.

28. Jenne DE, Reimann H, Nezu J, et al. Peutz-Jeghers syndrome is caused by mutations in a novel serine threonine kinase. Nat Genet 1998;18(1):38-43. DOI: 10.1038/ng0198-38.

29. Giacinti C, Giordano A. RB and cell cycle progression. Oncogene 2006;25(38):5220-5227. Available at: 10.1038/sj.onc.1209615.

30. Knudsen ES, Wang JYJ. Targeting the RB-pathway in cancer therapy. Clin Cancer Res 2010;16(4):1094. [Online]. Available at: 10.1158/10780432.CCR-09-0787.

31. Cadoni G, Boccia S, Petrelli L, et al. A review of genetic epidemiology of head and neck cancer related to polymorphisms in metabolic genes, cell cycle control and alcohol metabolism. Acta Otorhinolaryngol Ital 2012;32(1):1-11. https://www.ncbi.nIm.nih.gov/pmc/articles/ PMC3324962/.

32. Varley JM. Germline TP53 mutations and Li-Fraumeni syndrome. Hum Mutat 2003;21(3):313-320. DOI: 10.1002/humu.10185.

33. Hisada M, Garber JE, Li FP, et al. Multiple primary cancers in families with Li-Fraumeni syndrome. J Natl Cancer Inst 1998;90(8):606-611. DOI: 10.1093/jnci/90.8.606.

34. Vogelstein B, Sur S, Prives C. p53: the most frequently altered gene in human cancers. Nat Educat 2010;3(9):6. Available at: http://www. nature.com/scitable/topicpage/p53-themost-frequently-alteredgene-in-14192717.

35. Sun W, Califano JA. Sequencing the head and neck cancer genome: implications for therapy. Ann N Y Acad Sci 2015;1333(1):33-42. [Online]. Available at: 10.1111/nyas.12599.

36. Lassaletta L, Brandáriz JA, Benito A, et al. p53 expression in locally advanced pharyngeal squamous cell carcinoma. Arch Otolaryngol Head Neck Surg 1999;125(12):1356-1359. DOI: 10.1001/ archotol.125.12.1356[Online]. Available at: https://www.ncbi.nlm.nih. gov/pubmed/10604414.

37. Mroz EA, Rocco JW. Intra-tumor heterogeneity in head and neck cancer and its clinical implications. World J Otorhinolaryngol-Head and Neck Surg 2016;2(2):60-67. [Online]. Available at: http://dx.doi. org/10.1016/j.wjorl.2016.05.007.

38. Griewank KG, van de Nes J, Schilling B, et al. Genetic and clinico-pathologic analysis of metastatic uveal melanoma. Mod Pathol 2014;27(2):175-183. [Online]. Available at: 10.1038/ modpathol.2013.138. 


\section{Appendix 1: Methodology for Sequencing}

A total of 8 to $10 \mu \mathrm{g}$ of intact double-stranded high-quality gDNA, quantified fluorometrically (Qubit) for each sample with an absorbance ratio (A 260/280) of $\sim 1.8$ to 2.0, and a minimum concentration of 100 to $500 \mathrm{ng} / \mu \mathrm{L}$ was utilized.

\section{Work Flow for Sequencing Using Illumina Sequencing Platform}

A custom panel (consisting of 48 genes) was designed by Triesta labs for this study based on target enrichment methods. A probe set containing pairs of oligonucleotides specific to the targeted regions were hybridized to each genomic DNA sample. The Amplicons were generated by connection of bound oligonucleotides by extension and ligation using a DNA polymerase and ligase, followed by PCR amplification. The PCR primers were flanked by index sequences for sample multiplexing as well as common adapters for sequencing cluster generation.

After PCR cleanup, the library quality was assessed on a Bioanalyzer Tape station (Agilent Technologies, Santa Clara,
California, USA). Each sample library was normalized according to the manufacturer's instructions, and equal volumes were pooled to generate the final sequencing library.

\section{NGS Data Analysis}

Each pooled library was sequenced on the Illumina sequencing instrument using paired-end sequencing design $(2 \times 100)$. The image processing and fastq file generation from raw read data were done with CASAVA version 1.8.2 and RTA version 1.17.28 (Illumina). The alignment of paired-end raw reads to the human hg19 genome assembly was performed with a BWA algorithm. The variant calling and coverage analysis was performed by an in-house bioinformatics pipeline (GATK/STRELKA) at Triesta laboratories. The variants were filtered and annotated by VARMINER and OncoMD software. The variants with a global minor allele frequency $>1.0 \%$ were removed. The Integrative Genomics Viewer 16 (Broad Institute, Cambridge, Massachusetts, USA) was used to visualize variants against the reference genome. 